長崎港常盤・出島地区計画における屋外博物館の計画

\title{
Open Air Museum Project in Tokiwa-Dejima Area, Nagasaki Harbor
}

横松宗治 $*$, 後藤患之輔 $* *$, 林一馬 $* * *$

By Muneharu YOKOMATSU, Keinosuke GOTOH, Kazuma HAYASHI

In the 20th century the idea of preservation was developed. And in recent 20years, people have started to recognize the importance of the civil work muscums in many places.

The issue of preservation was triggered by the ruin of Parthenon as the restoration of old architectural style. And now the issue has been changed to the environment as a whole.

From 1991 to 2000, "Open Air Museum including Deiima wharf" has been planned in Tokiwa-Dejima district. This museum is not for a specific article nor a facility. Main purpose of this museum is to reconstruct and exhibit the ancient civil works which played important roll in forming the city of Nagasaki. Secondary, as this new district has many products and facilities of civil engineering and civic design, we should exhibit these heritage to the general public.

\section{1.はじめに}

近作十木遗産についてその保存、保全について 様ざまな試みがなされている1。本研究では、まず 保你、保全の思想的な変遷、発展について巡る。

一方、博物館もその領域を桩大し、土木施設、士 木計画の分野を主要な対象とするものも多く設置 されるようになった。上木学会誌においても、上木 情物館についての別绰を刊行した2?。同誌で举げら れた 89 博物館中、屋外博物館として直接的に土木 施設を保全するもの、上木施設の仩組みを屋外で 説时、解説する博物館は 15 館である。

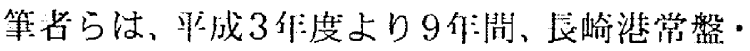
胉島地区計画に参西した。この計画のなかで、都 门長崳と辰崳港の歴史的な形成に関与した施設を 保企し、あるいは復元することを試みた。また士 木施没として興味深い、水路 (運河)、水辽坐態な ども屋外愽物館の展示事項の対象とした。

\section{2. 保全·保存の思想}

保全、保存 (conservation, preservation) の
概念は、建榴物の保存を図るなかで歴史的に形成 された。ここではまず、建筑界におけるその概念の 変遷を巡ってみる。歴史的な遗産の保存に関する 各時代の認識を象徵する「畫章」「宣言」を次に列 举する3)。

・マドリッド恚章（1904年、第6回国際建築家 会議）…遗産を「死んだモニュメント」と「生 きたモニュメント」に分ける。「生きたモニュ メント」は使われつづけるため修復 (restore) する。建筑にとって、有益性は美 しさの根拠の一つ」という理念である。

・アテネ憲章（1931 年）…国際博物館事務局の 呼びかけにより開催された。19 世紀末〜20 世紀前半の Nicolaos Balanosによるバルテ ノンの修復 エ事の批判、反省のなかからその 思想が形成された。

・「ベニス萝章」(1964作）‥20 世紀の保存理念 の代表的な思想である。モニュメントの保謢 だけではなく、枚史的な価值そのものに注目 した。序文において、「真正な価值 (authenticity)」が初めて具体的に使われ た。最小限の干渉 (minimum intervention)
Keywords: 屋外博物館、長畸、保全、保存

*正会員 侏式会社日本設計、名古屋市立大学大 学院䒧術工学研究科講帥（非常勤）
（干 163-1329 東京都新宿区西新宿 6-5-1)

**正会員 長崎大学社会開発工学科教授、博士 (工)

*** 長崎総合科学大学建築学科教授、博上(工) 
を基本とする。この䏚イコモスが設立され た。

・バラ憲帝（1981年）‥オオーストラリア・イコ モスによって倠成される。守るべきものを monumentからより広い概念としてのplace へと搪大し、歴史的に織りなされた多栐な睘

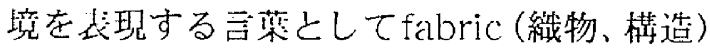
という概念が設定された。ここにはヨーーロッ バ的ではない新人陸の保全概念が認められ る。

・奈良ドキュメント（1994行）…世界文化遗产 佘良コンファレンスにおいて、点正な侕值、 真奏性、本物であること (authenticity) が 議論の机上に上つた。つまり「川本的」保存 の概念、木造建築（伊爹神宮など）の保你に ついて、新たな思想が登場した。非ヨーロッ バ文化圈での「保存」、「保金」の思想の形成 である。

要するに、保存の概念は、徐々に歴史的な厳格 さを獲得してきた。またその概念が、西洋を離㧈る ことによって动がりを得た。新大陸家州において、 環境の文脈の中での保存、保企という思想の樑化 を獲得した。さらに月本、アジアにおいて「保存」 自体の意味を問うことになった。

石の文化、キリスト教（一神教）の文化を背景
にした「保存」思想は、先験的に「永久的」、「碀結 的」そして「孤立的」保存を紧のこととする。と ころが、新人㓌において「器境」を、日㤝、アジア において「非永久、非淑結」を、保企概念のなかに 令めることになったおけである。

3. 长崎渄常盤・出岛地凶訶画の概要

計曲地は、長崎㴽の東望側約 14haであり、烧你 の出岛率壁の域を命む。

兒在埋め立て!:事が充了し、一部は供用をはじめ ている。背後には、怆帛、グラバー畦など観光スボッ トが多く集槙している。叮治の閒滺期に百洋人に よって形成された山手地区外国人位宅样、恫、欧 米条国领事館、外国銀行などが立地した人洲海学通 りに按している(図-1)。

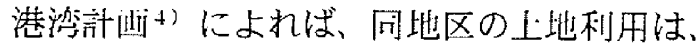

（1）公共施設、济栄施設などの建築用地、

（2）大規模な屋外イベントと川忙の川常の公周とし ての臨港緑地、

（3）水路沎いの、飲食、物眅施設なども計山部さ、 観光客の酦わいも予想される「水辺のフロムナード」によって構成される。

計幽地忛央の水路は、降测時には背後の館队地区 の雨水放流水路となる。水路の大型観光船据壁側

図-1 長崎港常盤・怕岛地区計画全休図

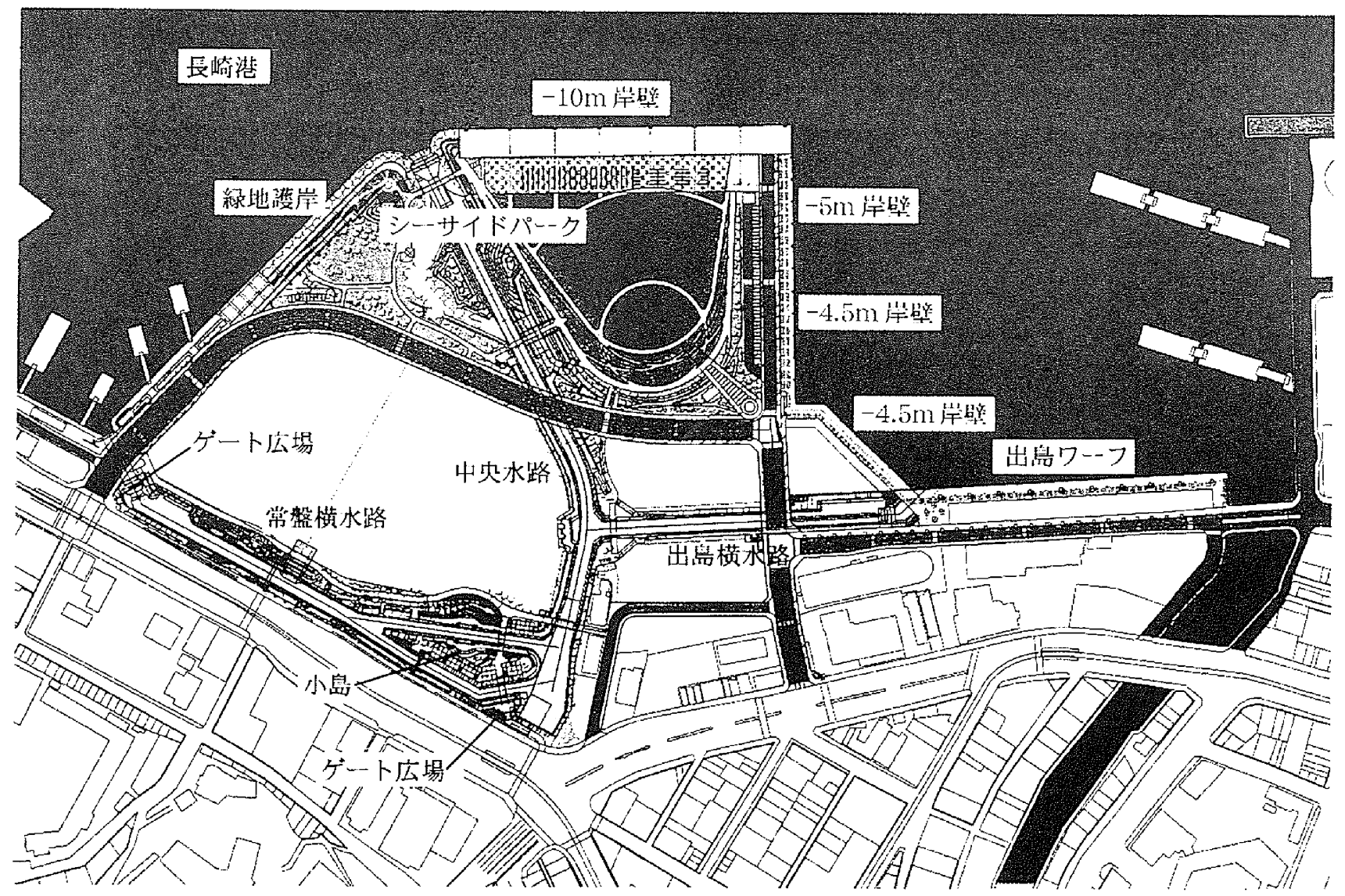


は、大規幙なオーフンスベースとして、多人数の集 まるイベントなどの利用に低される。このオーブン スヘースと川快の水路を挟んだ仪刘側は、水面と樹

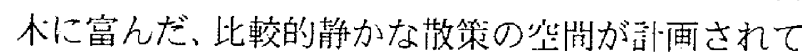
いる。

\section{1. 朴地区の屋外博物館の計画}

本地义鲉画では、次章に述べる9乎項について 展示を実施する計山である。

博物館の展示事项は、歷史博物館にみられるよ うに歴史的な物品、斗象の保存展小が・般的であ るが、近年の白然博物館や上木博物館などでは、贵 重な事物、興味ある事象の解説展示なども学及し てきた。

長琦港常盤・狛地区計幽は、歷史都市長崎の

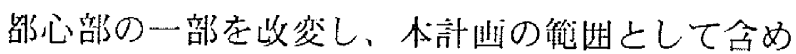
た部分と、新規に浩湾海面を埋立て造成された部 分とがある。従って、屋外博物館には、麻史的事物

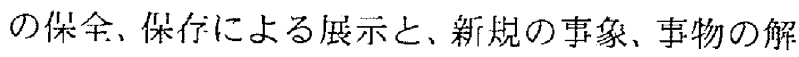
説展小゙とがある。

婊示の種別は以下の 3 種颣になる。

展小種斺一1。歴史的な满造物の犬物が现存し、 その一部を保余する。
既に先州性を失って、いわゆる遗满となってい るものを、保存 (Conservation) し、展示するも のが一般的である。そして上木施設の川には木だ その機能を維徖し、活为されているものもある。そ の機能を果たしながら当該施設を保企 (Preservation) し、展示するものもある。

「保存」と「保企」の定義は、必ずしも確定して いない。またその䒺馀（Conservation、 Preservation）も同様である。本諭文では、いわ ゆる“漱結的保存”に「保存」を、周辺環境を含め その機能を維持しながらの保存に「保全」の用語を 使用することとする。

展小種斺-2. 歴史的に覚重な土木施設が、現在 は存在しないが、歴史的な事実を物話る構造物を 復元 (Reconstruction) し、教育的な展示物とす る。

一般に上木栭造物は周辺の罍境、施設と分かち がたく・体的な機能を有している場合が多い。構 造物だけを切り離し竅内博物館に展示しても、そ の機能と存在の意義を説明することは困難である。 そこで、现地、かつてその權造物が生きて使用され た場所に復元展ホすするこが効果的である。

しかしながら、復元に伴う宿命的な「本物性、真 il: (Authenticity)」の問題が生まれる。前 2 章で

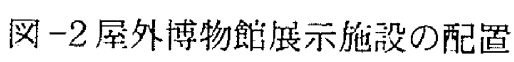

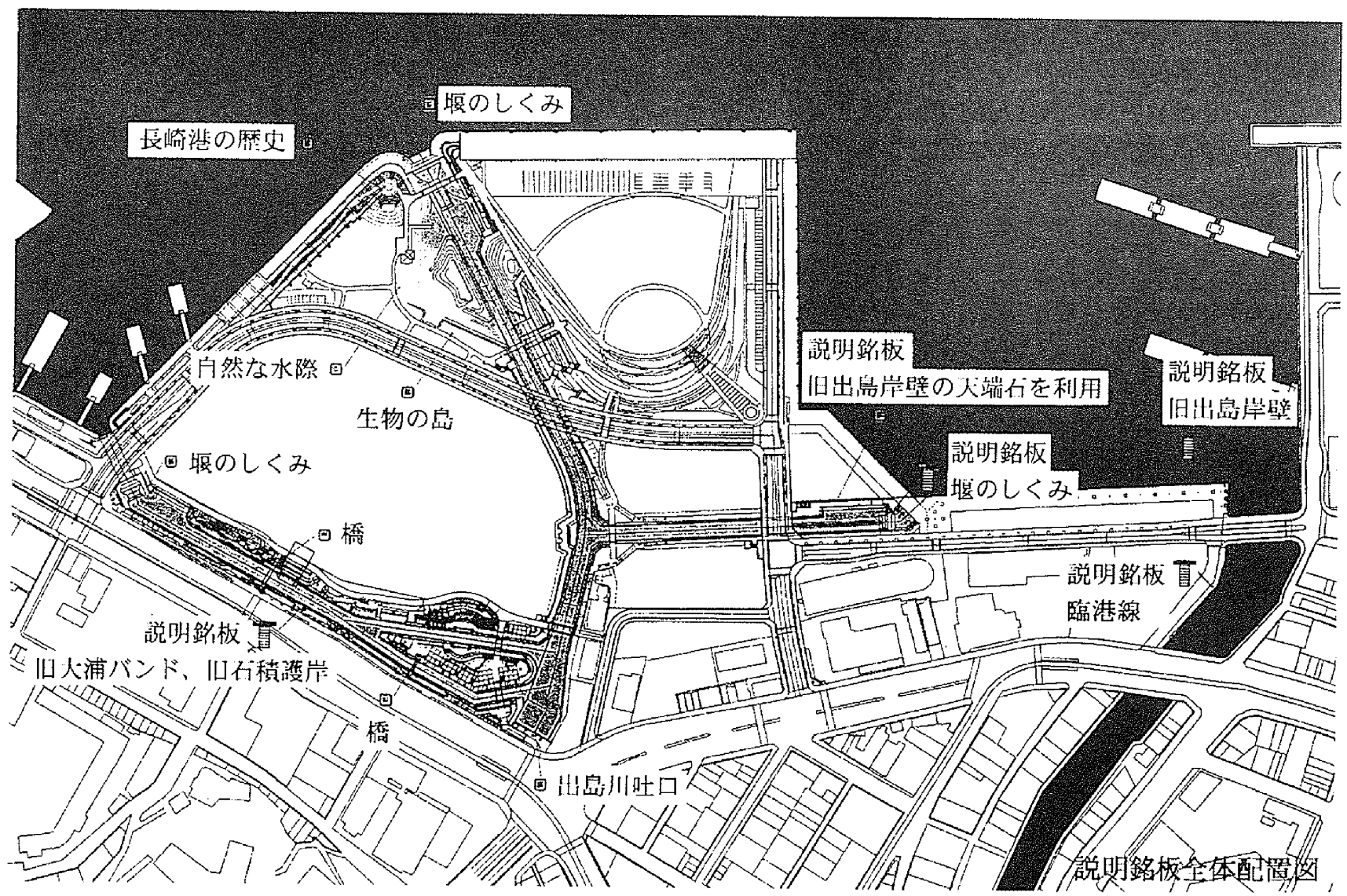


述べたように建栄界では、アテネ䖯章（1931作） の頃よりこの本物性、真四ささが議論の対象となっ てきた。上木界においては、近年復元がなされ始 め、ようやくこのAuthenticityの課題に直面する ことになってきた。

展示種別 -3. 十、的に興味ある構造物、仕組み を建設した。これらを解祱し、教材とする。

屋外土木博物館は、䄳史的な土木樥造物の、意 義を説朋、解説することが第 の役割である。つま り、長崎港が、わが国の近代化に果たした役制を位 筐づけることである。

本計画では、運河の計画をはじめ、都行計画上、 あるいは土木技術上:興味ある様ざまな施設を計幽・ 設計・施工した。これらの施設を説时・解説するこ とが、第二の役割である。

\section{5. 展示を実施した事项}

現地において奏施された 4 事項についてその展示 内容 ${ }^{5}$ 、保全·展示の意味を述べる。

\section{-1.出島岸壁について‥「長崎みなとのはなし」第} 1 話として

出島岸壁は、長崎港第三期港湾改良.事によっ て筑造された。1923作に長崳一上海航路が開設さ れ、1943年に廃此されるまで、近代長崎の黄金時 代の象徵である。

本展示では、出島岸壁の歷史と、ケーソン工法 を含め、その断面㩐造を標識で表示した。岸壁先端 の自然石は、一度取り外し、修復したうえで再設置 した (写真 -1$)$ 。

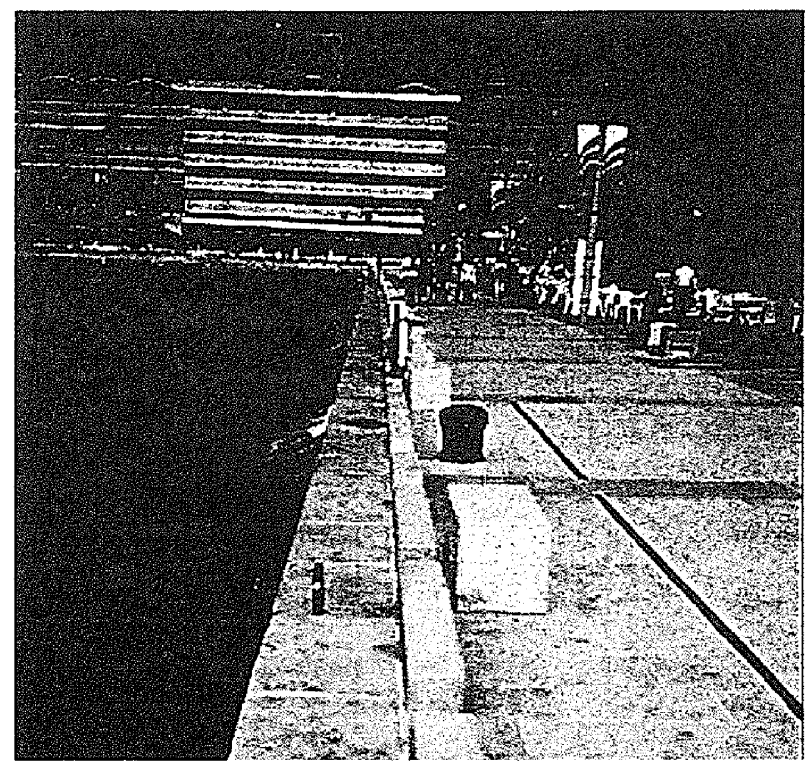

写真 -1 旧・出島岸壁の先端石
嵌壁から広場に改修された範冊においては、猞 装の・部としてその先端白然们を敷き込んだ。山 来の慰壁の位置を示している（写点-2）。

上記4.における展示種别一-1。相以する。

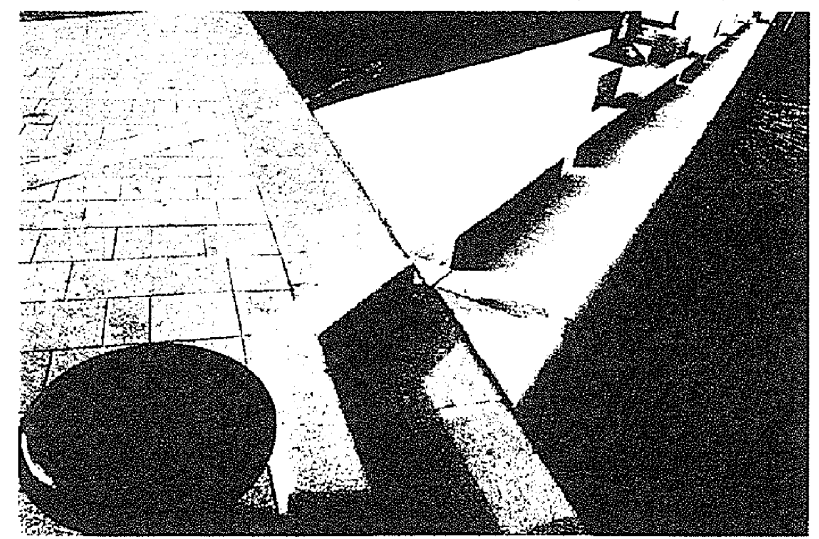

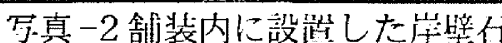

-2.臨港鉄道長崎港駅について‥長猗みなとのは なし」第 2 話として

1865 年、我が国初の鉄道（展示用）がこの附近 に放設された。そして長崎に海航路の開設に合す せて、辰崳駅より出岛岸壁まで臨港鉄道が設哭さ

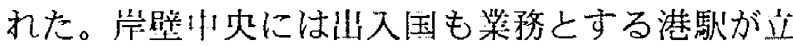
地した（写蒖 -3$) 。$

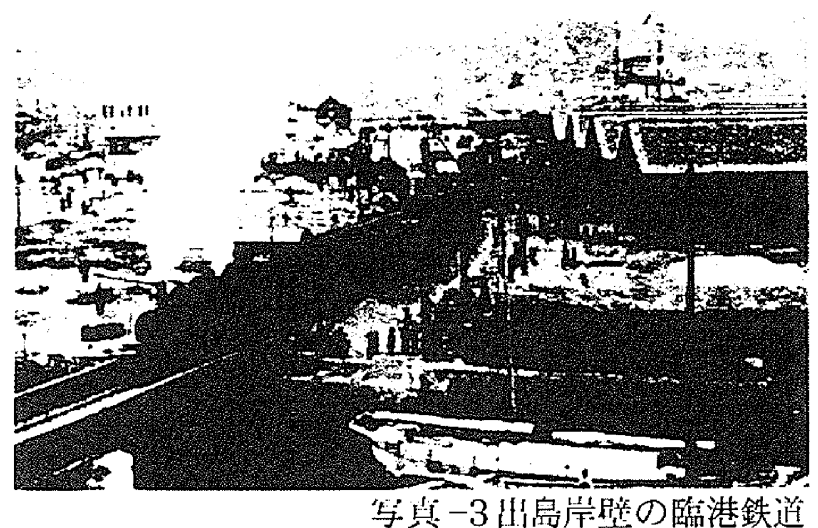

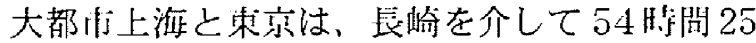
分で維ばれる。20 世糺解半の港湓都市長崎は、こ の上海航路のターミナル、出烏岸壁と長崎港駅に 中心があった。

鉄道と駅の份在を兒在まで残すものは、鉄道夥 が見在の長崎䭾から出㿟までの緑地 (遊步道)とし て土地利用されていることと、中島川護岸の一部 となった橋脚である。ここでは、鉄道の一部を当時 の位置に復元した。サインとしての動輪も設置し た(写真 -4$)$ 。

上記 4.における展示種別 -2 . に相当する。

-3. 堰のしくみ…哐崳みなとのはなし」第 3 話と して 
図 -3 潮汐と水路の仕組み

長崎港

港内の干満
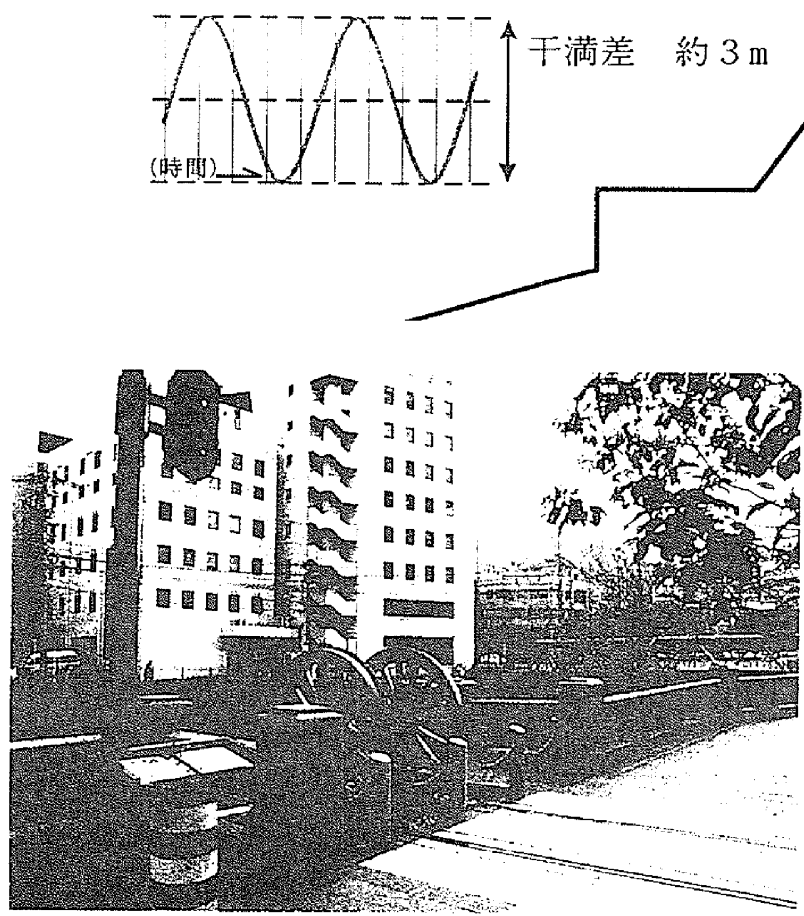

写点 -4 旧鉄路の復元

本地区の水路は外海と慗がっている。外海の潮 汐の水面の上下が水路水面に連動する。干满差が 約 $3 \mathrm{~m}$ であるため、河口部に「潜り腰」を設けた（写 真一5)。下潮胙にも水面への親近感を損なわない ためである。

まず海而の干满の見象を説明する。つぎに干満 に影響された水路内の水面の上下動を説明する。

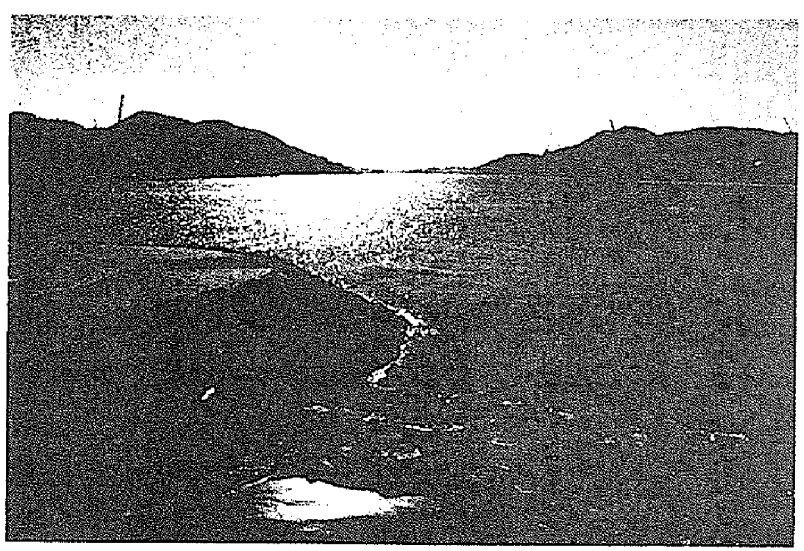

写点 -5 水路河口部の潜り堰

さらに潮汐軽動が、水路の縦断力向の海水の川入 りを伴うことを説时する。基本的には、水質の維持 は、この水路内の海水が、外海と出入りすることに よっていることを解説する。

最後に、自然石を吐蝵みされた水路護岸の、空

\section{水路}

水路内の干満

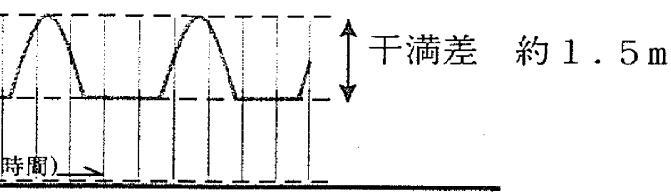

隙に生きる小さな生物の存在を記している。

ここでの展示は、上記 4. に打ける展示種別 -3 . に相当し、興味ある自然現象と水路の仕組みを解 説し、学童、生徒们けの教材とするものである(図一 $3)$ 。

\section{-4. 大浦居留地（大浦バンド）の船着き場}

長崎の近代開港期（幕末～朾治末）に昭着き場 がバンド（海岸通り）に筑造された。我われは、当 琮の地図之吉写真によって知るのみであった（写 真-6)。今回の水路工事によって、地中より発掘さ れた。水路護岸部にその一部を保全した（写点一 7)。

これは、上記 4. における展示種別 -1 . に相当す る。解説のための標識は、未だ設置されていない。

以下の各事項は、現在、計画段階であり、現地 では末だ実施されていない。

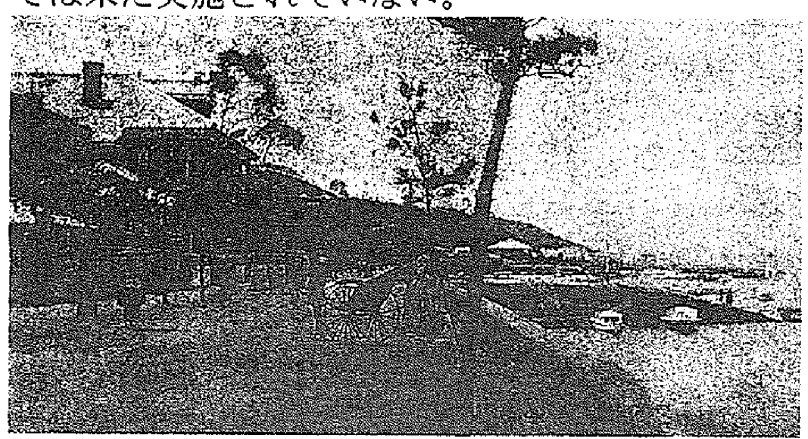

与点 -6 居留地の配置

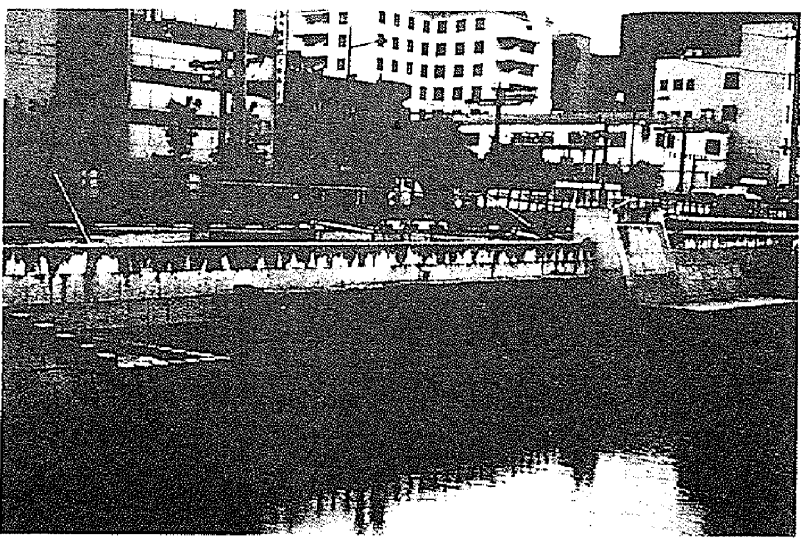

写真 -7 保全された船着き場の一部 


\section{-5.水路に架かる橋梁群}

17 世紀、長崎川帛川には多くの不造ア一于橋が 架設された。またり治期にも初期の近代橋梁、特に 鉄製橋梁には现任も保全され使出されているもの もある。怕川水系には、橋梁の歴史においては、 特にその資料が豊富に存任する。

本計画においては、水路に11個所の橋が架かる ア定である。橋梁博物館として展示の対集とする ことができる。

\section{-6. 水路内の「生物の島」}

臨海部の埋め立て地は、牛態的な環境は極めて 贫困である。このような環境において豊かな生物 相を保全するためには、人為的な抑压を兔れる领 域が必要である。水路内に、人間の立ち入れない囬 を造る。水中、水辺生物や鳥頪は、この島を逃避領 域とする。都市䍗境における生㶨系の観祭にも好 都合である。

\section{-7. 水路の水際}

港湾区域の水際は、ほぼコンクリート護岸と なっている。本来水際は、生態としては最も多様性 を持ち得る空間である。本計画地の水路队では、上 に述べた「白然石空䄼み」以外にも生物の島に接し て、「干潟」を計画している。水際の生態系につい て説明、解説する計画である。

\section{-8.出島川の姓き口}

館内地域の雨水排水路䌽岛川が、本水路に䋈が る。

長崎大水害 (1982年) の経験を語り継ぎ、雨水 排水計画を市民に啓蒙することは都市づくりの基 本的な要件である。出島川の吐き口、本水路との接 合地点に説明図、解説板を設置する計画である。

\section{-9. 長崎港の歷史}

本計画は、長崎港の歴史においても、大きな要 素を加えることになる。16 世紀後半の開港以来、 我が国の海外交流史において大きな足跡となって きた。本計画地において、その歴史を辿る説明展示 を行うことは大きな意味がある。

\section{6.おわりに}

筆者らは、長崎港常盤・出島地区訃画において、 平成 3 年から平成 12 年 3 月まで検討委員とコンサ ルタントとして参画した。既存市街地をも含む

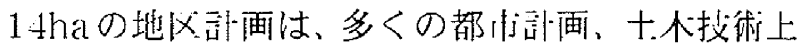
の課题を投げかけた。なかでも长崳近代閒滺期に 䚲成された港沵海紫施設は、上木史にとどまらず、 わが国の近代都川の歴史に㧍ける貴重な歴史的な 教材となり得る。

新地区の造成を進めながら、その比区内尒域を 対象に厓外士木博物館を計画、尖施した。その丁 法、資料の保企、解説は未完成、皆全ではあるが、 今後の沐題を捉供するものであると思う。湖々の 要素の展小は一応の端緒についたものと考える。 だが、それらの展采要素を体系的に解説する施設 は末だ検討されていない。「都市形成史」を基䂾に したセンター施設の㔍想を待つものである。

本文中にも述べたが、真价 (Authenticity) の 問題は、上木施設の復元に関してはとりわけ重要 であるが、今後の課題である。

またここで、基本的な問題に立ち返る必要があ る。

“なぜ保存·保全か?”

・過去からのメッセージを、伝統の生きた証拠、 歴史的な証拠として保護する。

・環竟のコンテクストを世代を超えて形成、保 全していく。

この問題は、士木あるいは建造物の保存、保企 の筑䀬を超えて検詿する課題である。地域史そし て人間環境形成の本質に係わる問題であり、今後 の破究課題である。

本論文の、「保存、保全」の思想的な部分は、日 本イコモス国内枩员会理事田原幸夫氏に多くの教 示を得たことを記し媣く感謝する。また9作間にお たって、このような機会を与えていただいた長崎 㿟臨海閒発局、水辺のブロムナード検討㚣員会㚣 員および関係各位に感謝する。

\section{参考文献}

1）東京大学土木工学研究会『平成 11 年度第 4 回 土木遗産の保全と計画・設計』(财) 総合研究奖 励化会

2) 土木学会『DOBOKU 上木博物館めぐり』土木 学会誌別冊增刊 1996-6Vol.81-7

3）田原幸夫「ユネスコ・イコモス、そしてドコモ モ」建築文化 2000 年 6 月号

4）長崎県県臨海開発局「長崎港港汾計画」平成 3 年 5）長崎芘臨海開発局、株式会社日本設計「長崳 港地域総合整備工事報告書」平成 12 年 3 月 